\title{
STUDI LITERATUR: IMPLEMENT ASI GOOD CORPORATE GOVERNANCE PADA BISNIS KELUARGA
}

\author{
a'Salma Annisa, ${ }^{\mathrm{b}}$ Muhammad Rizal, ${ }^{\mathrm{c}}$ Tetty Herawaty \\ a,b,c Universitas Padjadjaran \\ salma17011@mail.unpad.ac.id
}

\begin{tabular}{l|l|l} 
Received : October & Accepted : October & Published: December
\end{tabular}

\begin{abstract}
ABSTRAK
STUDI LITERATUR: IMPLEMENTASI GOOD CORPORATE GOVERNANCE PADA BISNIS KELUARGA. Duniabisnis dilanda VUCA. Agar perusahaan dapat bertahan dan berkembang dalam lingkungan bisnis yang kompetitif, maka perusahaan perlu melakukan upaya untuk mengamankan dan mengelola perusahaan. Salah satu perusahaan yang sangat memerlukan sistem tata kelola perusahaan adalah perusahaan keluarga. Karena terdapat kepentingan bisnis dan keluarga di sebuah perusahaan, hal tersebut dapat menimbulkan konflik dalam pengambilan keputusan yang akan berdampak pada keberlanjutan perusahaan. Penelitian ini merupakan studi literatur yang bertujuan untuk memberikan gambaran implementasi sistem tata kelola perusahaan pada bisnis keluarga. Hasil studi menemukan bahwa bisnis keluarga sangat membutuhkan implementasi sistem tata kelola perusahaan karena terdapat kesulitan dalam mempertahankan bisnis keluarga tersebut sampai generasi ketiga. Implementasi tersebut dapat dimaksimalkan berdasarkan prinsip transparency, accountability, responsibility, independency, fairness yang akan sangat membantu perusahaan dalam suksesi keberlanjutan perkembangan bisnis bagi generasi-generasi selanjutnya.
\end{abstract}

Kata kunci: Good Corporate Governance; Family Firm, Business Governance

\section{ABSTRACT}

\begin{abstract}
LITERATURE STUDY:IMPLEMENTATIONOFGOOD CORPORATE GOVERNANCE IN FAMIL YBUSINESSES. The business world is beset by VUCA. In order for a company to survive and thrive in a competitive business environment, it needs to make efforts to secure and manage the company. One company that really needs a corporate governance system is a family company. Because there are business and family interests in a company, it can lead to conflicts in decision making that will have an impact on the sustainability of the company. This research is a literature study that aims to provide an overview of the implementation of corporate governance systems in family businesses. Based on the results of analysis from literature studies, family businesses are in dire need of implementation of corporate governance systems because there are difficulties in maintaining the family business until the third generation. The implementation can be maximized based on the principles of transparency, accountability, responsibility, independency, fairness that will greatly assist the company in the succession of business development sustainability for future generations.
\end{abstract}

Keyword: Good Corporate Governance; Family Firm, Business Governance 


\section{PENDAHULUAN}

Seperti yang kita semua tahu, dunia bisnis saat ini dilanda VUCA. Hal tersebut membuat bisnis terus menghadapi tantangan yang lebih rumit lagi setiap harinya. Perusahaan yang bergerak di bidang jasa, perdagangan, dan manufaktur yang telah berkembang pesat akan selalu dihadapkan pada masalah manajemen dan pengendalian perusahaan. Agar perusahaan dapat bertahan dan berkembang dalam lingkungan bisnis yang kompetitif, maka perusahaan perlu melakukan upaya untuk mengamankan dan mengelola perusahaan. Salah satu hal yang perlu dilakukan untuk menerapkan tata kelola perusahaan yang baik di perusahaan (Ade Kesuma, Husni Mubarok, and Marisa 2020). Corporate Governance berkaitan dengan masalah tindakan atas permasalahan yang sering dihadapi para pemangku dominasi yang besar untuk menyugesti keputusan. Hampir di semua pasar global, para pemegang saham perusahaan terbesar yang paling umum adalah keluarga (Itan and Lestari 2015).

Penelitian mengenai bisnis keluarga sudah banyak dilakukan (Muhammad Halim Maimun 2019). Bisnis keluarga memiliki peranan yang sangat penting dalam berkontribusi terhadap produk bruto nasional. Di Indonesia, bisnis keluarga mendominasi sebagian besar bisnis dan tersebar di berbagai bidang industri dan organisasi (Lieyanto and Indriyani 2014). Badan Pusat Statistik (BPS) menyebutkan bahwa sektor swasta yang didominasi oleh perusahaan keluarga memiliki kontribusi hingga 82,44\% terhadap Pendapatan Domestik Bruto (BPS, 2014).

Namun bisnis keluarga masih memiliki banyak tantangan atas keberlanjutan bisnisnya dalam jangka waktu yang panjang (Widyanti Diah Lestari 2018). Kebanyakan bisnis keluarga tidak mampu melewati generasi ketiganya (Lam, 2011). Tantangan yang sering dihadapi oleh bisnis keluarga adalah kebanyakan manajer dan pemilik bisnis adalah orang yang sama. Maka dari itu akan muncul konflik dalam menyeimbangkan kepentingan keluarga dengan usaha keluarga, sehingga umumnya terdapat pertarungan atas kepentingan tersebut. Bisnis keluarga memiliki kemungkinan yang cukup besar untuk mempertimbangkan permasalahan saat pengambilan keputusan, karena keputusan yang diambil akan berdampak terhadap kemungkinan pertumbuhan perusahaan serta juga mempengaruhi kemampuannya buat membentuk atau mempertahankan tingkat kemakmuran yang diperoleh oleh anggota keluarga, yang bisa mempunyai akibat pada jangka panjang.

Pentingnya sebuah strategi tata kelola perusahaan dibutuhkan dalam keberlanjutan bisnis keluarga. Kebutuhan akan peran tata kelola perusahaan menjadi prinsip utama yang mampu dijadikan acuan untuk mengatasinya. Selain mengidentifikasi prioritas, seni manajemen, asal daya dan kekuatan untuk membantu menyeimbangkan dua kepentingan yang ada, yaitu buat mengurangi pertarungan sebagai akibatnya kepentingan keluarga dan usaha bisa berjalan menggunakan baik (Pounder, 2015). Tata kelola perusahaan lebih terkait dengan faktor penting dalam perusahaan seperti kepemilikan, kontrol, dan akuntabilitas perusahaan. Juga bagaimana sebuah perusahaan mendorong tujuan ekonomi yang terkait dengan sejumlah nilai etika dan pertimbangan sosial yang lebih luas.

Tata kelola bisnis keluarga sangat dibutuhkan karena merupakan sistem proses dan struktur yang diterapkan pada tingkat tertinggi bisnis, keluarga, dan kepemilikan untuk membuat keputusan sebaik mungkin mengenai arah bisnis dan jaminan akuntabilitas dan kontrol. Dalam bisnis keluarga yang berkembang dengan baik, ini melibatkan pemahaman bagaimana bisnis dan struktur tata kelolanya (Gallo and Rouvinez, 2005). Namun dalam bisnis keluarga, penerapan strategi yang baik dari satu generasi ke generasi selanjutnya tidaklah mudah. Terdapat perbedaan pendapat sudut pandang yang menjadi salah satu masalah utama dalam penerapan prinsip tata kelola perusahaan pada bisnis keluarga sulit dilakukan. Sering kali bisnis keluarga tidak mengutamakan penerapan tata kelola perusahaan karena menganggap shareholder perusahaan merupakan anggota keluarga sehingga tingkat kepercayaan terhadap pengelolaan perusahaan sangat tinggi (Chrisnanda 2014).

Penerapan strategi sistem tata kelola dalam bisnis keluarga sangat dibutuhkan dalam membentuk suatu sistem pada perusahaan dalam menutupi kekurangan bisnis keluarga dan menyeimbangkan seluruh bagian perusahaan. Sistem tata kelola akan membuat bisnis 
keluarga dapat berlangsung lama dan berkelanjutan dari generasi ke generasi selanjutnya serta menghindari adanya konflik dalam pengambilan keputusan bisnis keluarga (Purwanto and Mustamu 2013). Berdasarkan penjelasan di atas, penelitian ini bertujuan untuk menggambarkan sebuah keadaan atau fenomena mengenai penerapan sistem tata kelola perusahaan pada bisnis keluarga. Hal tersebut dapat menambah pemahaman dalam melakukan Tindakan yang dilakukan langsung oleh pihak-pihak yang terlibat dalam praktik suksesi tata kelola bisnis keluarga. Dengan demikian, penelitian ini dapat dijadikan sebagai acuan bagi para pebisnis keluarga dalam menjalankan strategi sistem tata kelola perusahaannya.

\section{KAJIAN LITERATUR}

\section{Bisnis Keluarga}

Suatu bisnis dapat dikatakan merupakan bisnis keluarga apabila terdiri dari dua atau lebih anggota keluarga yang mengawasi keuangan perusahaan (Rahadi 2017). Pengertian lain menyebutkan bahwa sebuah organisasi dapat dinamakan bisnis keluarga apabila terdapat keterlibatan dua generasi dalam keluarga tersebut yang mempengaruhi kebijakan perusahaan (Jauwalatta et al. 2016). Bisnis keluarga dapat ditinjau dari 3 aspek, yaitu:

1. Mayoritas kepemilikan saham dimiliki oleh keluarga tersebut dan mengontrol keseluruhan bisnis tersebut.

2. Terdapat anggota keluarga dalam manajemen perusahaan tersebut yang menempati posisi kunci.

3. Terdapat suksesi yang menjaga kepemilikan perusahaan agar dapat terus menerus berjalan.

Maka dapat dikatakan bisnis keluarga merupakan bisnis yang dikelola dan dimiliki oleh anggota keluarga yang terlibat dalam seluruh proses, di antaranya pengambilan keputusan, penyusunan kebijakan dan strategi, serta menjabat pada posisi kuncidi perusahaan tersebut (Andypratama and Mustamu 2013).

Terdapat beberapa tahapan dalam mengembangkan bisnis keluarga (Hasan 2018). Gambar 1 menjelaskan mengenai model lima tahapan bisnis keluarga.

\section{Gambar 1. Lima Tahap Bisnis Keluarga Sumber: Hasan, 2018}

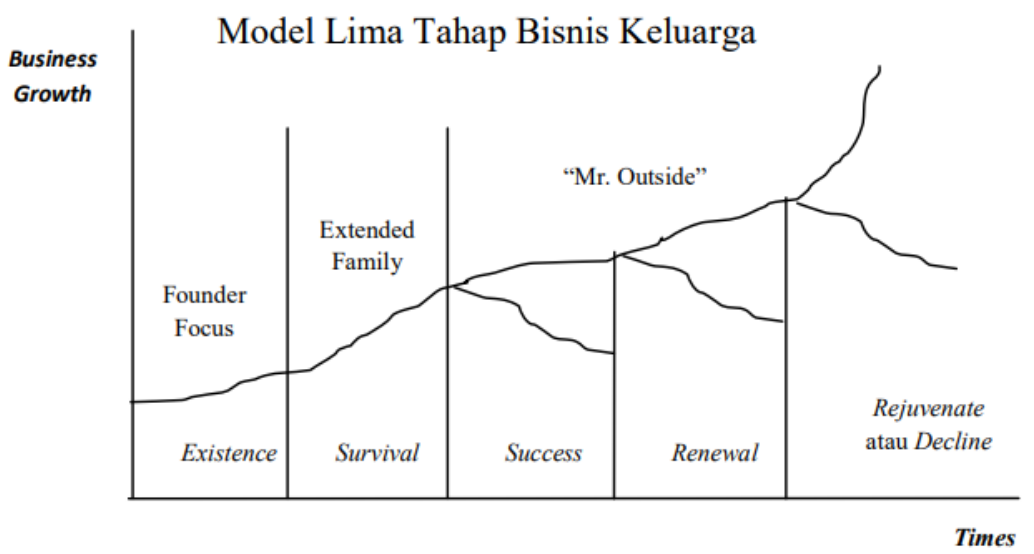

Gambar 1 menjelaskan perkembangan bisnis keluarga yang dapat digunakan sebagai pedoman dan petunjuk dalam menentukan kapan sebaiknya pendiri perusahaan mempersiapkan diri dalam menentukan, mendidik serta menyerahkan kelanjutan tanggung jawab bisnis keluarga yang dipegangnya selama ini pada generasi penerusnya, serta apa saja tantangan yang kemungkinan akan dihadapi oleh generasi penerus bisnis keluarga sebelumnya. Fase kritis umumnya terjadi saat terjadinya proses suksesi, sehingga umumnya akan menghipnotis prospek keberlanjutan bisnis keluarga yang akan kembali atau justru mengalami penurunan dan kemudian kehancuran (Bisnis, Fella, and Kristianti 2020). Maka 
dari itu, proses suksesi merupakan sebuah tahapan yang harus dilewati perusahaan keluarga, sehingga wajib direncanakan dengan baik serta sistematis demi keberlanjutan perusahaan keluarga di masa mendatang baik jangka pendek maupun jangka panjang (Remiasa and Wijaya 2014).

\section{Konflik dalam Bisnis Keluarga}

Dalam terminologi bisnis, terdapat 2 jenis perusahaan famili, yaitu FOE (Family Owned Enterprise) serta FBE (Family Business Enterprise) (Susanto, 2007). FOE adalah perusahaan yang kepemilikannya dimiliki oleh keluarga, namun dikelola oleh pihak profesional di luar keluarga. Pada kategori FOE, keluarga berperan sebagai pemilik namun tidak terlibat pada kegiatan operasionalisasi perusahaan agar pengelolaan perusahaan berjalan secara profesional. Berdasarkan pembagian peran ini, anggota keluarga dapat lebih mengoptimalkan fungsi supervisi. Sering kali, perusahaan tipe ini merupakan lanjutan asal usaha yang semula dikelola sang keluarga yang mendirikan. Sedangkan, FBE memiliki arti perusahaan yang dimiliki dan dikelola oleh anggota famili pendirinya. Baik kepemimpinan maupun pengelolaannya dipegang sang pihak yang sama yaitu keluarga. Bisnis keluarga kategori FBE mempercayakan posisi-posisi kunci perusahaannya pada anggota keluarga (Tjiptono 2013).

Di Indonesia, kebanyakan bisnis keluarga berkategori FBE di mana para anggota keluarga merupakan pengelolanya. Pada praktiknya, semakin berkembang perusahaan, semakin kompleks juga dinamika yang terjadi. Dinamika yang tinggi tentu membutuhkan kompetensi yang tinggi pula bagi pengelolanya. Bila kebutuhan akan kompetensi ini tidak terpenuhi oleh anggota keluarga maka diperlukan suntikan energi asal luar lingkungan keluarga. Suntikan tenaga berasal luar inilah yang dinamakan pihak professional (Aldamen et al. 2020). Di sini pihak profesional akan membantu pihak keluarga dalam menjalankan perusahaannya. namun, pada pengelolaan perusahaan keluarga sering kali terjadi bentrok antara pihak keluarga dengan pihak profesional yang mengatur juga mengelola perusahaan, karena masing-masing pihak antara owner (pemilik) juga control (pengendali) memiliki kepentingannya sendiri, hal ini diklaim dengan permasalahan kepentingan (Sacristán-Navarro and Cabeza-García 2020).

Jika perusahaan keluarga berbentuk perseroan terbatas, maka pertarungan yang mampu terjadi merupakan perseteruan antara kepemilikan saham dominan dan saham minoritas (outside investor), di mana info yang terdapat dalam perusahaan dipegang sang pihak mayoritas, dan pihak minoritas tidak mengetahui info juga keadaan yang sebenarnya dalam perusahaan (Sacristán-Navarro and Cabeza-García 2020). Hal ini ditimbulkan sebab perusahaan keluarga yang berbentuk perseroan terbatas mempunyai tanggung jawab tidak terbatas pada kewajiban-kewajiban bisnisnya. Menjadi aturan umumnya, pemegang saham perusahaan tidak mempunyaitanggung jawab langsung buat hutang-hutang perusahaan atau tanggung jawab lain pada luar nilai investasinya di perusahaan (Azila-Gbettor et al. 2018). Oleh karena itu, perusahaan keluarga jenis ini akan membantu melindungi aset-aset eksklusif milik pemegang saham. Pemilik perusahaan keluarga membatasi perpindahan liabilitas saham untuk menjamin kepemilikan usaha permanen dipegang oleh keluarga (Aldamen et al. 2020). Untuk menjaga agar kepemilikan bisnis dipegang oleh pihak keluarga atau pemegang saham secara umum dikuasai, maka isu maupun keputusan yang terdapat tak jarang dipegang sang dominan, pemegang saham minoritas (outside investor) tidak mendapatkan isu-info ataupun hak-hak yang sebenarnya. Hal ini yang memicu perseteruan antara dominan dan minoritas. Selain daripada hal tadi, budaya atau norma pada perusahaan lebih berdasarkan hubungan dibandingkan sesuai hukum yang ketat (Kristanti, Rahayu, and Huda 2016). Maka sering kali timbul permasalahan antara anggota keluarga di dalam perusahaan. Permasalahan tersebut mengakibatkan dampak negatif bagi perusahaan baik bagi internal perusahaan maupun eksternal perusahaan. Agar bisa menyelesaikan permasalahan ataupun perseteruan yang terdapat maka perlu adanya pemahaman perihal prinsip-prinsip Good Corporate Governance (GCG); (Cornwallis dan Kusmanto, 2009). Tidak hanya berhenti sampai di pemahaman saja, akan tetapi perlu adanya upaya buat pengimplementasian prinsip-prinsip di dalam perusahaan tadi. GCG umumnya belum diterapkan pada perusahaan keluarga. Kebutuhan prosedur tersebut sangat lah penting tatkala perusahaan famili 
berkembang menjadi perusahaan akbar di mana pengelolaannya cukup susah. diharapkan menggunakan dikembangkan prosedur tadi bisa mengendalikan perusahaan secara efektif sekaligus menjaga kepentingan shareholder serta stakeholder, serta menghindari supaya tidak terjadi konflik-pertarungan pada perusahaan (Agus and Mcgowan 2021).

\section{Good Corporate Governance}

Perkembangan topik Corporate Governance sebelumnya hanya bersifat marginal, namun kini mulai berubah menjadi topik sentral. Oleh karena itu, dibutuhkan pemahaman yang memadai tentang Corporate Governance(Nuryan, 2016). Menurut IICG (The Indonesian Institute of Corporate Governance) Corporate Governance merupakan sebuah proses atas struktur yang diterapkan dalam perusahaan dengan tujuan untuk meningkatkan nilai pemegang saham dalam jangka panjang dengan tetap memperhatikan kepentingan stakeholders (IICG, 2013). Pengertian lain mengenai Corporate Governance adalah sistem dan struktur untuk mengelola perusahaan dengan tujuan meningkatkan nilai pemegang saham (shareholders) seperti kreditor, pemasok, asosiasi usaha, konsumen, pekerja, pemerintah dan masyarakat luas (Tunggal, 2013).

Pengertian konsep Corporate Governance dapat dimasukkan dalam 2 kategori. Kategori pertama lebih cenderung pada sebuah pola sikap perusahaan yang diukur melalui kinerja, perkambangan perusahaan, struktur pembiayaan, perlakuan kepada para pemegang saham, dan stakeholders. Kategori kedua, lebih melihat pada kerangka secara normatif, yaitu segala ketentuan aturan baik yang berasal dari sistem hukum, sistem peradilan, pasar keuangan serta sebagainya yang mempengaruhi sikap perusahaan Good Corporate Governancemerupakan suatu hukum tentang pengelolaan perusahaan yang perlu diterapkan di setiap perusahaan (Lozano, Martínez, and Pindado 2016). Berdasarkan beberapa pengertian di atas dapat dikatakan bahwa Good Corporate Governance merupakan sebuah strategi yang harus dimiliki oleh perusahaan dalam mengelola keseluruhan sistem bisnisnya untuk dapat memaksimalkan pengambilan keputusan dan meminimalisir konflik yang berdampak kepada keberlanjutan bisnis tersebut.

Good Corporate Governance memiliki empat prinsip yang diterapkan (Sedarmayanti, 2012), yaitu:

1. Fairness (Kewajaran) Perlakuan yang sama terhadap pemegang saham minoritas dan pemegang saham asing, dengan keterbukaan informasi yang penting serta melarang pembagian untuk pihak sendiri dan perdagangan saham oleh orang dalam.

2. Disclosure dan Transparency (Transparansi) Hak pemegang saham dalam pengambilan keputusan mengenai perubahan mendasar atas perusahaan.

3. Accountability (Akuntabilitas) Pengawasan efektif berdasarkan keseimbangan kekuasaan antar manajer, pemegang saham, dewan komisaris, dan auditor merupakan bentuk pertanggung jawaban manajemen kepada perusahaan dan pemegang saham.

\section{METODE}

Penelitian pada kajian ini menggunakan metode penelitian deskriptif, yaitu sebuah penelitian yang bertujuan untuk menyampaikan atau menjabarkan suatu keadaan atau kenyataan yang terjadi menggunakan prosedur ilmiah untuk menjawab masalah secara aktual (Sugiyono, 2012). Penelitian ini merupakan penelitian kajian literatur yang bertujuan untuk menggambarkan fenomena penerapan Good Corporate Governance pada bisnis keluarga secara ilmiah berdasarkan hasil kajian literatur yang ada. Data yang digunakan adalah data sekunder yang diperoleh dari hasil analisis kajian literatur yang sudah ada mengenai implementasi penerapan Good Corporate Governance pada bisnis keluarga. Pendekatan yang digunakan adalah pendekatan kualitatif. 


\section{HASIL DAN PEMBAHASAN}

Berdasarkan hasil analisis studi literatur sistematis mengenai implementasi penerapan Good Corporate Governance pada bisnis keluarga, hal pertama yang harus dilakukan adalah mengidentifikasi bisnis keluarga tersebut termasuk ke dalam kategori Family Owned Enterprise (FOE) atau Family Business Enterprise (FBE). Berdasarkan kategorisasi bisnis keluarga tersebut akan lebih lanjut diketahui mengenai detail modal, pembagian keuntungan, kepemilikan, serta pengelolaan yang dijalankan pada perusahaan tersebut.

Pada bisnis keluarga kategori FOE, perusahaan sudah mempercayakan keberlangsungan perusahaannya kepada pihak profesional atas seluruh kegiatan operasionalnya. Maka dari itu pada bisnis keluarga kategori FOE, sistem penggajian sudah dilakukan benar-benar secara profesional yang didasarkan pada tingkatan jabatan dan hasil kinerja yang diatur oleh peraturan perusahaan. Walaupun sudah berjalan sepenuhnya secara profesional, namun nilai-nilai keluarga yang ditanamkan oleh pendiri perusahaan masih akan selalu dipegang sebagai prinsip dalam meneruskan perusahaan. Hal tersebut sangat penting dalam rangka menjaga kerukunan antar anggota keluarga sehingga tidak terjadi perpecahan atau konflik keluarga dalam perusahaan sehingga seluruh pihak dapat mengutamakan kepentingan dan kemajuan perusahaan bukan kepentingan pribadi.

Sedangkan pada bisnis keluarga kategori FBE, seluruh kegiatan operasional masih dimiliki, dijalankan, dan dikelola oleh anggota keluarga pendirinya. Karena itu masih banyak timbul konflik terutama dalam masalah suksesi perusahaan. Hal tersebut sesuai dengan teori bahwa sering muncul isu-isu konflik dalam suksesi bisnis keluarga antara calon-calon penerus (Agus and Mcgowan 2021). Keberhasilan suksesi bisnis keluarga dapat dilihat dari perpindahan kepemimpinan dari generasi sebelumnya ke generasi selanjutnya. Keberhasilan perpindahan kepemimpinan antar generasi akan berbanding lurus dengan keberlangsungan dan keberlanjutan perusahaan ke depannya. Calon penerus potensial dapat didiskusikan dari proses dan tahapan pembelajaran yang dapat dilihat dari seberapa besar minat dan kompetensi calon penerus potensial yang ada.

Selanjutnya untuk dapat mengetahui lebih lanjut dan mendalam mengenai penerapan Good Corporate Governance pada bisnis keluarga dapat ditinjau melalui prinsip-prinsip Transparancy, Accountability, Responsibility, Independency dan Fairness dalam mencapai tujuan perusahaan tersebut

\section{Transparancy}

Dalam melihat prinsip transparansi, terdapat dua indikator yang dapat dijadikan acuan, yaitu indikator informasi dan kebijakan yang ada di suatu perusahaan. Berdasarkan prinsip transparansi, perusahaan dituntut untuk dapat menyediakan seluruh informasi dan kebijakan yang ada dengan mudah diakses dan mudah dipahami oleh seluruh anggota perusahaan.

\section{Informasi}

Indikator informasi sudah berjalan baik atau belum dapat dilihat dari keterbukaan informasi yang terjadi di perusahaan tersebut. Dibutuhkan kejelasan informasi yang disampaikan dan penggunaan media penyampaian yang mendukung. Informasi yang dimaksud bukan hanya informasi mengenai pengambilan keputusan, namun juga termasuk seluruh informasi yang bersifat umum seperti peraturan perusahaan, tujuan perusahaan, sistem keuangan, sistem produksi, sanksi, visi misi perusahaan, dan lainnya.

Keterbukaan informasi yang baik seharusnya dapat disampaikan kepada seluruh anggota perusahaan secara transparan, bukan hanya pada tingkatan posisi atau jabatan tertentu atau divisi tertentu. Informasi yang baik dapat diakses dengan setara dari hulu ke hilir, dari pimpinan sampai ke bawahan. Beberapa informasi bahkan perlu diolah lagi agar dapat dipahami dengan baik khususnya pada level bawahan. Untuk mempermudah kesetaraan akses informasi tersebut, perusahaan sebaiknya memanfaatkan penggunaan berbagai macam media, seperti email, aplikasi pesan 
digital (Whatsap, Line BBM, dlI), sms, maupun telepon. Penggunaan media ini dapat memaksimalkan penyampaian informasi ke seluruh anggota perusahaan secara lebih efektif dan efisien (Juwita 2019).

\section{Kebijakan}

Kebijakan perusahaan juga perlu disampaikan dengan sangat jelas dan dapat diakses dengan mudah oleh seluruh anggota perusahaan. Kebijakan yang dibentuk oleh para pimpinan didasarkan atas kepentingan setiap anggotanya. Kebijakan yang dibentuk, di antaranya adalah peraturan perusahaan, standar operasional perusahaan, ketentuan kenaikan jabatan, dll.

Sama seperti penyampaian informasi, penyampaian kebijakan juga akan lebih maksimal jika dapat memanfaatkan media penyampaian yang mendukung (Nurim, Reni, and Anggraini 2019). Perusahaan dapat menyampaikan kebijakan-kebijakan yang ada dengan menempatkan informasi kebijakan tersebut di bagian dinding perusahaan yang dapat dengan mudah diakses oleh seluruh anggota. Perusahaan juga dapat mengadakan rapat atau diskusi rutin dalam menginformasikan secara detail dan terbuka mengenai kebijakan yang ada. Perusahaan juga dapat menyebarluaskan soft copy kebijakan-kebijakan tersebut melalui email atau media lainnya.

\section{Accountability}

Prinsip akuntabilitas dalam penerapan sistem kelola perusahaan adalah bagaimana perusahaan dapat mempertanggung jawabkan kinerjanya. Untuk dapat mempertanggung jawabkan secara baik, perusahaan harus dikelola secara benar dan terukur sesuai tujuan perusahaan. Terdapat dua indikator yang dapat diukur dari akuntabilitas perusahaan, yaitu basis kerja dan audit.

\section{Basis Kerja}

Basis kerja perusahaan dapat dilihat berdasarkan struktur perusahaan yang ada dan sistem manajemen yang dijalankan perusahaan tersebut. Perusahaan yang baik adalah perusahaan yang memiliki struktur organisasi yang jelas. Terdapat tingkatan jabatan yang jelas yang membawahi berbagai divisi yang ada. Struktur organisasi yang baik tidak memperbolehkan rangkap jabatan pada anggotanya karena hal tersebut akan membuat peran tersebut tidak maksimal karena tidak fokus dalam salah satu fungsi tanggung jawabnya (Yopie and Itan 2016). Hal tersebut juga tidak sesuai dengan undang-undang perseroan terbatas.

Pembagian tugas dan wewenang juga harus dilaksanakan secara jelas dan transparan agar setiap anggota perusahaan benar-benar mengerti tugas dan tanggung jawab masing-masing dan kepada siapa mereka harus bertanggung jawab. Untuk dapat mendukung kejelasan tersebut, diperlukan adanya SOP perusahaan sesuai dengan tugas dan tanggung jawab masing-masing divisi yang ada. SOP akan membantu birokrasi perusahaan akan berjalan lebih jelas dan teratur.

\footnotetext{
Audit

Sistem audit di sebuah perusahaan dapat bersumber dari internal dan eksternal. Audit internal yang dilakukan perusahaan mencakup audit cash flow, material, laporan keuangan, dan buyer \& seller. Audit internal dapat dilakukan tiga bulan sekali, enam bulan sekali, bahkan satu tahun sekali tergantung pada bagian yang harus diaudit untuk mengetahui kinerja perusahaan pada periode audit tersebut. Tujuannya adalah untuk mengetahui dan mengkoreksi apakah sudah sesuai dan mencapai target yang ditetapkan (Yudha and Singapurwoko 2017). Hasil dari audit tersebut adalah sebagai evaluasi bersama bagi para shareholder dan stakeholder. Pada audit eksternal, perusahaan menggunakan auditor dari luar perusahaan yang dapat menganalisis penerapan sistem yang sudah dijalankan perusahaan. Auditor
} 
eksternal ini akan lebih objektif dan transparan dalam memberikan informasi mengenai keadaaan sebenarnya dari kinerja perusahaan.

\section{Responsibility}

Penerapan prinsip responsibilitas perusahaan harus sesuai dengan peraturan perundang-undangan dan bertanggung jawab kepada masyarakat dan lingkungan sehingga terciptanya keberlanjutan jangka panjang perusahaan. Terdapat dua indikator dalam melihat resposibilitas perusahaan dalam penerapan Good Corporate Governance, yaitu Corporate Social Responsibility (CSR) dan kepatuhan (compliance) atas pertaturan perundang-undangan.

\section{Corporate Social Responsibility (CSR)}

Corporate Social Responsibility (CSR) perusahaan dapat dilihat dari tiga aspek, yaitu lingkungan, karyawan, dan masyarakat. Pada aspek lingkungan, perusahaan yang bertanggung jawab adalah perusahaan yang menjamin higienitas atas produk yang dihasilkan. Higienitas produk tidak hanya dilihat dari hasil produk jadi, namun dari limbah yang dihasilkan atas proses pembuatannya. Perusahaan perlu membentuk tim khusus yang bertanggung jawab atas higienitas produk dan limbah atas proses produksi tersebut sesuai dengan peraturan yang berlaku. Limbah akan sangat berdampak pada pencemaran lingkungan sekitar. Perusahaan harus mengolah limbah dengan sebaik-baiknya agar tidak mencarkan lingkungan sekitar dan membahayakan masyarakat sekitar sesuai dengan SOP dan peraturan yang ada.

Pada aspek masyarakat, perusahaan dapat mendistribusikan produk-produk sisa yang belum expired untuk diberikan kepada yayasan-yayasan sosial seperti panti asuhan atau panti jompo. Perusahaan juga dapat memberikan bantuan berupa fasilitas yang dapat bermanfaat bagi masyarakat sekitar. Tidak hanya masyarakat sekitar, perusahaan juga dapat memberikan bantuan atas korban bencana, atau beasiswa pendidikan kepada masyarakat secara umum dan luas.

Pada aspek karyawan, perusahaan wajib menjamin kesejahteraan keryawannya. Selain upah, perusahaan juga perlu memfasilitasi berbagai tunjangan yang ada seperti BPJS atau jamsostek. Perusahaan juga dapat memberikan tunjangan berbentuk non-tunai seperti sembako, smartphone, dll. Fasilitas yang diberikan perusahaan terhadap karyawannya juga merupakan peranan pertanggung jawaban yang diberikan perusahaan. Kelayakan dan kebersihan fasilitas kantor seperti ruang kerja, tempat ibadah, toilet, ruang rapat, dll merupakan pertanggung jawaban yang wajib disediakan oleh perusahaan.

\section{Kepatuhan (Compliance)}

Kepatuhan perusahaan atas perundang-undangan yang berlaku juga merupakan aspek yang dapat dilihat dari tanggung jawab yang diberikan perusahaan (Yasser 2011). Kepatuhan tersebut dapat dilihat dari berbagai macam hal, di antaranya ketaatan perusahaan dalam membayar pajak. Perusahaan yang bertanggung jawab pasti membayar pajak tepat waktu bahkan menggunakan jasa konsultan pajak.

Selain itu ketaatan perusahaan dalam penerapan aturan sesuai undangundang tenaga kerja. Perusahaan yang bertanggung jawab akan menjamin hak setiap karyawannya sesuai dengan UU tenaga kerja yang berlaku. Selain itu dokumen perizinan berdirinya perusahaan juga merupakan bukti ketaatan perusahaan terhadap undang-undang. Perusahaan yang patuh pasti memiliki dokumen perizinan yang jelas dan lengkap, seperti SIUP, NPWP, dll.

\section{Independency}

Sistem pengelolaan perusahaan telah memiliki prinsip independen yang baik apabila bagian-bagian dari perusahaan tidak saling mendominasi satu sama lain dan tidak saling mengintervensi. Perusahaan harus independen tanpa adanya pengaruh 
dari pihak mana pun yang didasarkan pada kepentingan pribadi (Azila-Gbettor et al. 2018). Pihak-pihak yang dapat mempengaruhi perusahaan adalah berasal dari dalam dan luar perusahaan. Pihak internal perusahaan dapat berasal dari para pemegang saham dan keluarga. Seluruh keputusan yang diambil oleh perusahaan harus berasal dari pemegang saham mayoritas dan sesuai dengan hasil Rapat Umum Pemegang Saham (RUPS) yang bersifat objektif. Apabila ada keluarga yang berperan dalam tugas dan wewenang perusahaan, keputusan yang diambil harus merupakan hasil objektif dari seluruh pihak yang terkait, bukan hanya hasil keputusan anggota keluarga saja.

Ada berbagai pihak eksternal yang mempengaruhi perusahaan, di antaranya pemerintah, serikat buruh, konsultan, dll. Peraturan pemerintah tentu akan sangat mempengaruhi terhadap keberlangsungan bisnis perusahaan. Perusahaan harus menyesuaikan strategi dan keputusan yang diambil sesuai dengan kebijakan pemerintah. Selain itu serikat buruh juga tentu akan mempengaruhi perusahaan karena asset utama dari perusahaan adalah karyawan itu sendiri, sehingga apabila hubungan antara perusahaan dan serikat buruh tidak baik maka kinerja perusahaan pun akan tidak maksimal. Kemudian penggunaan jasa konsultan pun berpengaruh terhadap perusahaan, khususnya dalam proses pengambilan keputusan. Konsultan tentu akan memberikan saran, masukan, dan opsi dalam pengambilan keputusan, namun wewenang pengambilan keputusan sepenuhnya dimiliki oleh perusahaan.

\section{Fairness}

Penerapan prinsip keadilan pada sistem tata kelola perusahaan merupakan kesetaraan dan kewaaran dalam pelaksanaan kegiatannya yang harus memperhatikan kepentingan para pemegang saham dan pihak-pihak kepemilikan perusahaan. Maka dari itu terdapat dua indikator dalam melihat prinsip keadilan, yaitu stakeholders dan shareholders.

\section{Shareholders}

Prinsip keadilan dari aspek shareholders dapat dilihat dari prosi kepemilikan saham atas pembagian haknya (Ing Malelak, Soehono, and Eunike 2020). Proses pembagian deviden sebagai hak kepemilikan akan berlangsung sesuai dengan Rapat Umum Pemegang Saham (RUPS) yang dihadiri oleh para pemegang saham tersebut. Seluruh pemegang saham baik itu mayoritas atau minoritas, memiliki hak yang sama dalam mendapatkan laporan keadaan perusahaan dan pembagian deviden sesuai porsi kepemilikannya. Selain itu, para pemegang saham juga memiliki hak untuk memberikan feedback atas kinerja perusahaan. Hal tersebut menjadi sangat penting pada bisnis eluarga karena biasanya kepercayaan berlandaskan hubungan kekeluargaan yang dimiliki oleh para shareholders.

\section{Stakeholders}

Prinsip keadilan atas aspek stakeholders dapat dilihat dari tindakan adil perusahaan dalam memenuhi hak dan kewajiban seluruh karyawannya (Harjito 2021). Pada proses rekrutmen, prosesnya harus berjalan secara objektif dan terbuka bagi umum. Kemudian perusahaan juga harus memberikan kesetaraan hak yang dimiliki oleh seluruh karyawan dalam memiliki kesempatan berkarir. Sistem punishment dan reward juga merupakan salah satu penerapan prinsip keadilan perusahaan. Sistem tersebut dapat meningkatkan kinerja para karyawan sehingga memunculkan nilai bahwa perusahaan merupakan perusahaan yang adil dan transparan atas kinerja karyawannya. Sanksi yang diberikan dapat berupa teguran lisan maupun tertulis. Sedangkan penghargaan yang diberikan dapat berupa tiket liburan, penambahan cuti/libur, apresiasi lisan, dll.

Berdasarkan pembahasan hasil studi, temuan tersebut dapat dijadikan sumber dasar sebagai langkah awal bagi peneliti dalam melakukan penelitian lebih lanjut mengenai identifikasi atas kajian good corporate governance pada bisnis keluarga. 
Peneliti dapat melanjutkan penelitian untuk mengetahui apakah terdapat hubungan sebab akibat atas implementasi good corporate governance dengan kinerja perusahaan keluarga atau dengan keberhasilan proses suksesi perusahaan keluarga.

\section{SIMPULAN}

Bisnis keluarga merupakan salah satu bisnis yang mendominasi di beberapa negara dan bahkan memberikan kontribusi yang besar bagi pertumbuhan ekonomi negara tersebut. Keberadaan dan keberlanjutannya tentu akan sangat berdampak positif bagi perekonomian negara. Namun sayangnya, bisnis keluarga bahkan sulit bertahan sampai generasi ketiganya. Hal tersebut dikarenakan atas konflik internal dari bisnis keluarga yang mengakibatkan terjadinya tumpeng tindih kepentingan antara kepentingan bisnis dan kepentingan keluarga. Konflik tersebut akan sangat berdampak terhadap proses pengambilan keputusan dan suksesi dari keberlangsungan bisnis keluarga itu sendiri.

Untuk mengatasi konflik tersebut, perusahaan sangat memerlukan penerapan sistem tata kelola perusahaan atau Good Corporate Governance agar keberlangsungan bisnis keluarga tersebut dapat memiliki umur panjang dan keberlanjutan. Praktik langsung penerapan sistem tata kelola perusahaan dapat diterapkan pada lima prinsip, yaitu Transparancy, Accountability, Responsibility, Independency, dan Fairness. Pada prinsip transparansi, perusahaan dapat menerapkan prinsip tersebut dari aspek kejelasan dan kesetaraan akses atas informasi dan kebijakan yang terdapat di perusahaan. Kemudian pada prinsip akuntabilitas, perusahaan dapat menerapkan prinsip tersebut dari pengelolaan sistem manajemen, kejelasan struktur organisasi dan tugas serta wewenang seluruh karyawannya, dan transparansi hasil audit kinerja perusahaan. Pada prinsip responsibilitas, perusahaan dapat menerapkan prinsip tersebut dari tanggung jawab yang diberikan oleh perusahaan atas karyawan, lingkungan, dan masyarakat melalui sistem Corporate Social Responsibility (CSR) dan kepatuhan perusahaan tersebut kepada undang-undang yang berlaku. Pada prinsip independen, perusahaan dapat menerapkan prinsip tersebut berdasarkan kemandirian perusahaan atas pengaruh atau intervensi dari pihak internal, seperti keluarga dan pemegang saham dan berbagai pihak eksternal yang berpengaruh seperti pemerintah, konsultan, dan serikat buruh. Pada prinsip yang terakhir, yaitu keadilan perusahaan dapat menerapkan prinsip tersebut berdasarkan kesetaraan hak dan kewajiban yang diberikan oleh perusahaan kepada para stakeholders dan shareholders.

Kelima prinsip tersebut akan sangat membantu bisnis keluarga dalam menerapkan sistem tata kelola perusahaan yang baik sehingga dapat mengatasi konflik internalnya dalam pengambilan keputusan dan suksesi keberlangsungan dan keberlanjutan perusahaan. Sehingga setelah menerapkan sistem tata kelola perusahaan, bisnis keluarga dapat menjadi bisnis yang berkelanjutan sampai generasi-generasi selanjutnya yang akan terus berkontribusi positif bagi perekonomian negara.

Penelitian ini memiliki keterbatasan, yaitu hanya berfokus pada impelemntasi good corporate governance pada bisnis atau perusahaan keluarga. Selain itu, sumber database elektronik yang digunakan hanyalah berasal dari Google Scholar dan Scopus. Peneliti menyarankan kepada peneliti lain yang ingin meneliti kajian ini untuk mencoba lokus penelitian lain selain perusahaan keluarga, misalnya pada industry startup yang saat ini sedang menjadi fenomena yang ramai dibicarakan. Kemudian bisa memperluas sumber database elektronik yang digunakan.

\section{REFERENSI}

Ade Kesuma, Sambas, Muhammad Husni Mubarok, and Citra Marisa. 2020. "Business Ethics: A Connection to Good Corporate Governance Implementation." Jurnal Perspektif Pembiayaan Dan Pembangunan Daerah 8 (2): 2338-4603. https://doi.org/10.22437/ppd.v8i1.7877. 
Agus, D, and Carl B Mcgowan. 2021. "The Effect Of Corporate Governance And Corporate Strategy On Family Firm Performance In Indonesia." The Journal of Applied Business Research. Vol. 37.

Aldamen, Husam, Keith Duncan, Simone Kelly, and Ray McNamara. 2020. "Corporate Governance and Family Firm Performance during the Global Financial Crisis." Accounting and Finance 60 (2): 1673-1701. https://doi.org/10.1111/acfi.12508.

Andypratama, Lukas William, and Ronny H Mustamu. 2013. "PENERAPAN PRINSIPPRINSIP GOOD CORPORATE GOVERNANCE PADA PERUSAHAAN KELUARGA: STUDI DESKRIPTIF PADA DISTRIBUTOR MAKANAN." AGORA 1(1).

Azila-Gbettor, Edem M., Ben Q. Honyenuga, Marta M. Berent-Braun, and Ad Kil. 2018. "Structural Aspects of Corporate Governance and Family Firm Performance: A Systematic Review." Journal of Family Business Management. Emerald Group Holdings Ltd. https://doi.org/10.1108/JFBM-12-2017-0045.

Bisnis, Keberhasilan, Keluarga Fella, and Ika Kristianti. 2020. "Nominal: Barometer Riset Akuntansi Dan Manajemen." Nominal: Barometer Riset Akuntansi Dan Manajemen 9 (1): $1-18$.

Chrisnanda, Daniella Okke. 2014. "ANALISIS PENERAPAN GOOD CORPORATE GOVERNANCE PADA PERUSAHAAN KELUARGA PT. DANLIRIS DI SURAKARTA, JAWA TENGAH." AGORA2 (2).

Harjito, Agus. 2021. "The Effect Of Corporate Governance And Corporate Strategy On Family Firm."

Hasan, Muhammad. 2018. "PENDIDIKAN EKONOMI INFORMAL: BAGAIMANA PENDIDIKAN EKONOMI MEMBENTUK PENGETAHUAN PADA BISNIS KELUARGA?" JEKPEND: Jurnal Ekonomi Dan Pendidikan 1 (2): 30. https://doi.org/10.26858/jekpend.v1i2.7262.

IICG. 2013. Good Corporate Governance dalam Prespektif Pengetahuan. Laporan Program Riset dan Pemeringkatan Good Corporate Governance Perception Index 2012. IICG

Ing Malelak, Mariana, Christina Soehono, and Christine Eunike. 2020. "Corporate Governance, Family Ownership and Firm Value: Indonesia Evidence." SHS Web of Conferences 76: 01027. https://doi.org/10.1051/shsconf/20207601027.

Itan, Iskandar, and Widyanti Lestari. 2015. "Implikasi Corporate Governance Terhadap Kinerja Family Business Di Indonesia." Jurnal Ipteks Terapan 9 (1). https://doi.org/10.22216/jit.2015.v9i1.39.

Jauwalatta, Fendy, Kresna Noviaty, S Darmasetiawan, and M Si Psi. 2016. "PERENCANAAN SUKSESI PADA TOSERBA ' $X$ ' DITINJAU DARI FAMILY SYSTEM, MANAGEMENT SYSTEM DAN OWNERSHIP SYSTEM."

Juwita, Rakhmini. 2019. "The Effect of Corporate Governance and Family Ownership on Firm Value." Review of Integrative Business and Economics Research 8 (1): 168-78. http://buscompress.com/journal-home.html.

Kristanti, Farida Titik, Sri Rahayu, and Akhmad Nurul Huda. 2016. "The Determinant of Financial Distress on Indonesian Family Firm." Procedia - Social and Behavioral Sciences 219 (May): 440-47. https://doi.org/10.1016/j.sbspro.2016.05.018.

Lieyanto, Andy, and Ratih Indriyani. 2014. "PENERAPAN PRINSIP - PRINSIP GOOD CORPORATE GOVERNANCE PERUSAHAAN KELUARGA PT. PRIMA RAYA ABADI, SURABAYA." AGORA2 (1).

Lozano, M. Belén, Beatriz Martínez, and Julio Pindado. 2016. "Corporate Governance, Ownership and Firm Value: Drivers of Ownership as a Good Corporate Governance Mechanism." International Business Review 25 (6): 1333-43. https://doi.org/10.1016/j.ibusrev.2016.04.005.

Muhammad Halim Maimun, Syamsudin. 2019. "A REVIEW OF THEORETICAL PERSPECTIVE ON FAMILY BUSINESS GOVERNANCE.” BENEFIT Jurnal Manajemen Dan Bisnis 4 (1): 27-40.

Nurim, Yavida, Francisca Reni, and Retno Anggraini. 2019. "Collectivism and Uncertainty Avoidance on Family Firm and Corporate Governance Implementation: An Indonesia 
Case Study in Social Cognitive Theory Framework." Review of Integrative Business and Economics Research 8 (1): 179-94. http://buscompress.com/journal-home.html.

Purwanto, Gabriela Kartika, and Ronny H Mustamu. 2013. "STUDI DESKRIPTIF PENERAPAN PRINSIP-PRINSIP GOOD CORPORATE GOVERNANCE PADA PERUSAHAAN KELUARGA DI BIDANG KAYU." AGORA 1 (1).

Rahadi, Dedi Rianto. 2017. "TRANFORMASI INOVASI BISNIS KELUARGA DALAM MENDUKUNG EKONOMI KREATIF." Vol. 2. http://www.smetoolkit.org/.

Remiasa, Marcus, and Shelvy Anggraini Wijaya. 2014. "Analisis Proses Suksesi Perusahaan Keluarga Studi Pada PT Puterasean (Marcus Remiasa Dan Shelvy Anggraini Wljaya) ANALISIS PROSES SUKSESI PERUSAHAAN KELUARGA STUDI PADA PT PUTERASEAN."

Sacristán-Navarro, María, and Laura Cabeza-García. 2020. "When Family Firm Corporate Governance Fails: The Case of El Corte Inglés." Journal of Family Business Management 10 (2): 97-115. https://doi.org/10.1108/JFBM-02-2019-0010.

Tjiptono, Fandy. 2013. "Kelanggengan Entrepreneurship Dalam Bentuk Bisnis Keluarga: Apa Yang Telah Dan Masih Perlu Diungkap Fandy Tjiptono."

Widyanti Diah Lestari, R A. 2018. "STUDI FENOMENOLOGI: MEMAKNAI TATA KELOLA PERUSAHAAN PADA BISNIS KELUARGA BERETNIS TIONGHOA DI INDONESIA." Vol. 2.

Yasser, Qaiser Rafique. 2011. "Challenges in Corporate Governance - A Family Business Prospective." International Journal of Innovation 2 (1): 73-76.

Yopie, Santi, and Iskandar Itan. 2016. "CEO-Family vs. CEO-Nonfamily: Who Is a Better Value Creator in Family Business?" Vol. 14.

Yudha, Danies Pradana, and Arif Singapurwoko. 2017. "The Effect of Family and Internal Control on Family Firm Performance: Evidence from Indonesia Stock Exchange (IDX)." Journal of Business and Retail Management Research 11 (4): 68-75. https://doi.org/10.24052/jbrmr/v11is04/teofaicoffpefise. 